UDC 339.137.2

DOI: $10.18524 / 2303-9914.2020 .2(37) .216572$

L. V. Tranchenko ${ }^{1}, \operatorname{DrSc}$ (Economic), Prof,

V. V. Yavorska ${ }^{2}$, DrSc (Geography), Prof.

K. V. Kolomiyets ${ }^{2}$, PhD (Geography), Docent

${ }^{1}$ Uman National University of Horticulture

Department of Tourism and Hotel and Restaurant Business

Institute st., 1, Uman, Cherkasy region, 20305, Ukraine

${ }^{2}$ Odessa I. I. Mechnikov National University

Department of Economic and Social Geography and Tourism

Dvorianskaya St., 2, Odessa, 65082, Ukraine

yavorskaya@onu.edu.ua

\title{
DIRECTIONS OF ACTIVATION OF ECOTURISM DEVELOPMENT IN UKRAINE
}

This study raises issues related to the current state of ecotourism and prospects for its development in our country. Under ecological tourism we understand the form of nature-oriented tourism, carried out in order to learn about wildlife and destination culture, which does not violate the integrity of the ecosystem, designed to contribute to the conservation of natural resources, environmental protection and socio-economic development of the tourist area. According to the World Tourism Organization, Ukraine has great potential for the development of ecotourism and the opportunity to be on the list of leading countries in this area. However, there are a number of limitations and problems that restrain the more active development of ecotourism in Ukraine. The aim of the article is to investigate the reasons for the insufficient development of ecotourism in Ukraine and to substantiate the directions of its intensification in the country. The comparative characteristics of the areas of protected areas of the world and Ukraine indicate that in Ukraine and some CIS countries is dominated by a small number of protected areas, but with a large average area in contrast to countries such as Canada, Australia, Sweden, Norway, which have much more protected territories with their relatively small average area. It is noted that in Ukraine, in contrast to a number of foreign countries, where there are more accurate methods of calculating the tourist flow, it is very difficult to estimate the real flow of visitors to national parks, due to the lack of unambiguous methods of counting visitors. To promote ecological tourism, the administration of national parks is recommended to present parks at international tourism exhibitions, cooperate more actively with tour operators and travel agents, develop the park's infrastructure and recreational activities within it, offering tourists new routes.

Key words: ecological tourism, nature protection territories, national parks, reserves, destinations, tourist flows. 


\section{INTRODUCTION}

Today, ecotourism is one of the most promising sectors of the hospitality industry and occupies one of the leading positions [11, 12]. According to many experts, the share of ecotourism accounts for more than $10-20 \%$ of profits from the entire tourism market [13].

Ukraine is a huge country, with unique resorts, natural monuments, priceless national reserves and outstanding potential tourist attractions, but it still does not occupy a leading position among countries specializing in eco-tourism. The reason for this is not only a banal shortcoming for our country: in Ukraine, no type of tourism is properly developed, compared to other countries, which should be compared. All problems are due to lack of motivation, desire and funding. In today's world, people have learned to sell the craziest and most inconspicuous items. In this case, you do not need to invent anything; you just need to set the right priorities in the promotion of tourist attractions, in particular, ecological natural areas. There are examples of even underdeveloped countries that are highly popular among ecotourists. In countries such as Kenya, Ecuador, Costa Rica, and Nepal, it is the main source of income in foreign currency, with revenues of more than $\$ 723,1,551,3,665$, and $\$ 481$ million annually [14]. Thus, the aim of the article is to investigate the reasons for the insufficient development of ecotourism in Ukraine and to substantiate the directions of its intensification in the country.

\section{MATERIALS AND METHODS OF RESEARCH}

Theoretical, methodological and practical approaches to the development of ecological tourism were raised by Aleshugina N. O., Boreyko V. E., Galasyuk S. S., Dmytruk O. Y., Kifyak V. F., Kolesnyk O. O., Kravchenko N. O., Malska M. P. Such scientists as Arsenyeva O. I., Baikanova D. E., Vyshnevsky V. I., Vorobyova O. A., Dmitruk O. Y., Kobelka O. O., Kravchenko N. O., Lyubitseva O. O., Kuskov A. S., Shevchenko T. A. made a significant contribution to the development of the theoretical basis of tourism activities of ecological orientation, but the problems and prospects development of ecological tourism in Ukraine need further research.

The research methodology includes theoretical principles, methods and procedures of analysis that reveal the essence of ecotourism as a multifaceted phenomenon, an important part of the hospitality industry. The article uses general scientific research methods: analysis - to study the individual components of eco-tourism; synthesis - to combine individual facts; statistical method - for processing statistical information and for qualitative evaluation of data; method of induction and deduction - helps to draw conclusions based on existing facts; system approach - for a holistic study of the prospects of ecotourism in relation to external factors.

\section{RESEARCH RESULTS AND DISCUSSION}

The term "eco-tourism" is found in various contexts today quite often. The reason for this is the growing interest in "soft" forms of tourism, which are called, among 
other things, "nature-oriented" or "socially responsible", given that humanity has finally realized the devastating and global consequences of its industrial activities $[7,10]$.

Today, there are several dozen definitions of eco-tourism, most of which are reduced to environmental content. After analyzing most of the terms, we can present ours own interpretation of the term. Ecotourism is a form of nature-oriented tourism, carried out to learn about wildlife and destination culture, which does not violate the integrity of the ecosystem, is designed to contribute to the conservation of natural resources, environmental protection and socio-economic development of the tourist area.

Most types of tourism affect the socio-economic well-being of the areas where they develop, but often lead to environmental and anthropogenic problems. The only type of tourism that does not change or worsen the ecology of natural areas, but on the contrary, creates conditions for the maintenance and conservation of all types of natural resources - is ecotourism, which is very important in today's world, with the threat of ecological catastrophe and irresponsible attitude of mankind to the planet and everything that was created on it long before humans appeared. Ecotourism differs significantly from other forms by its positive impact on the sustainable development of natural areas, expressed in the balance of environmental, socio-cultural and economic impacts of tourism and resorts $[1,3,10]$.

Summarizing the above, we can identify the most important components of ecotourism:

- education of tourists - the creation of some educational tourism products with a naturalistic focus, aimed at expanding the knowledge and skills of tourists;

- preservation of ecosystems, which involves the careful use of resources along the route, the participation of tourists and tour operators in campaigns to protect wildlife;

- respect for the customs and traditions of local communities, which leads to opportunities for intercultural exchange.

Several recent trends have emerged under the influence of various factors operating the development of ecotourism. First, ecotourism is becoming more diverse as new forms and manifestations emerge. Secondly, there is a growing integration of ecotourism with other types of tourism and tourism industries. Proponents of the true meaning of ecotourism, which is reduced to environmental content, distracted by the increased negative impact of large flows of ecotourists, advocate a position aimed at banning any form of tourism in protected areas [5]. Despite their position, ecotourism has already become part of mass destinations, for example, in many cultural and cognitive or beach tours, resorts, as an excursion component, is a short-term visit to reserves, national parks and other protected areas $[2,6]$. Of course, the emergence of new trends changes the original meaning and significance of ecotourism and often blurs the concept of ecotourism.

Table 1 shows a comparative description of the data of protected areas of the 
world and Ukraine, but is based only on state particularly significant natural areas with a high level of protection.

Table 1

Comparative characteristics of protected areas of some countries *

\begin{tabular}{|l|l|c|c|c|}
\hline № & \multicolumn{1}{|c|}{ Country } & $\begin{array}{c}\text { Number of } \\
\text { protected areas }\end{array}$ & $\begin{array}{c}\text { Total area of } \\
\text { protected areas, } \\
\text { thousand ha }\end{array}$ & $\begin{array}{c}\text { Total area in \% } \\
\text { of the country's } \\
\text { territory }\end{array}$ \\
\hline 1 & USA & 803 & 54312 & $5.6 \%$ \\
\hline 2 & Australia & 2537 & 48473 & $6.3 \%$ \\
\hline 3 & Canada & 1814 & 45636 & $4.6 \%$ \\
\hline 4 & Russia & 144 & 42568 & $2 \%$ \\
\hline 5 & Indonesia & 122 & 5668 & $3 \%$ \\
\hline 6 & Sweden & 750 & 3928 & $8.7 \%$ \\
\hline 7 & India & 83 & 3562 & $1.1 \%$ \\
\hline 8 & New Zealand & 131 & 1933 & $7.2 \%$ \\
\hline 9 & Kazakhstan & 11 & 1672 & $0.6 \%$ \\
\hline 10 & Norway & 110 & 1529 & $4.7 \%$ \\
\hline 11 & Finland & 55 & 999 & $3 \%$ \\
\hline 12 & Turkmenistan & 8 & 820 & $1.7 \%$ \\
\hline 13 & Uzbekistan & 10 & 807 & $1.8 \%$ \\
\hline 14 & Ukraine & 25 & 800 & $1.3 \%$ \\
\hline 15 & Japan & 53 & 638 & $1.7 \%$ \\
\hline 16 & Italy & 17 & 442 & $1.5 \%$ \\
\hline 17 & Spain & 34 & 160 & $0.3 \%$ \\
\hline 18 & Germany & 8 & 129 & $0.4 \%$ \\
\hline 19 & Austria & 10 & 93 & $1.1 \%$ \\
\hline 20 & Denmark & 22 & $0.3 \%$ \\
\hline & & & & \\
\hline
\end{tabular}

* Compiled for $[4,9,13]$

According to the Table 1, we can conclude that the distribution of protected areas in the territory is organized differently in different countries. In Ukraine and some CIS countries, a small number of protected areas predominates, but with a large average square. And in countries such as Canada, Australia, Sweden, Norway there are many more protected areas with their relatively small average square. It is also worth noting that the total area of protected areas in Ukraine is almost equal to the protected areas in Canada, the United States and Australia, but our country is much inferior to the development of ecotourism [8].

According to the results of the accounting of territories and objects of the nature reserve fund, submitted by the executive authorities at the local level, ensuring the 
implementation of the state policy in the field of environmental protection, as of 01.01.2020 the nature reserve fund of Ukraine includes 8512 territories and objects with a total area of 4.418 million hectares within the territory of Ukraine (actual area 4.085 million hectares) and 402500.0 hectares within the Black Sea $[4,9]$.

The ratio of the actual area of the nature reserve fund to the area of the state («reserve indicator») is $6.77 \%$. During 2019, the number of objects and territories of the nature reserve fund of national and local significance increased by 116 units with a total area of 94,224.2 hectares. In 2019, 116 territories and objects of the nature reserve fund were created (announced), 9 were expanded, the area was reduced by 3 , status 1 was abolished and the category of 13 objects was changed.

In particular, in 2019 the area of the nature reserve fund increased the most in Rivne (by 22018.21 ha), Kherson (by 15911.84 ha), Zaporizhia (by 13115 ha), Lviv (by 12800.6471 ha) and Zakarpattia (on 11716.2 ha) areas. In Volyn, Kharkiv and Chernivtsi regions there have been no changes in the nature reserve fund.

Statistics show that in 2018, national parks and reserves of Ukraine were visited by more than 3.5 million people, of which more than $80 \%$ of the flow was accounted for by national parks $[4,9]$. However, it should be noted that in Ukraine, in contrast to a number of foreign countries, where there are more accurate methods of calculating the tourist flow, it is very difficult to assess the actual flow of visitors to national parks, due to lack of unambiguous methods of accounting. Thus, the true flow of tourists should be several times more than the data published in statistical reports, which means that the anthropogenic load on natural areas also exceeds the presented figures. It should be noted that more accurate data can be obtained mainly only on organized groups that have visited national parks and reserves, due to the fact that the directorate keeps strict records.

In 2018, the number of visitors to national nature parks and biosphere reserves was 131,155 tourists, which is $2.7 \%$ less than in 2017 . However, there is a positive dynamics of tourist flows in terms of individual objects of nature reserves [4]. Thus, in 2018, 2,720 visitors came to enjoy the amazing and unsurpassed landscapes of Europe's largest desert Oleshkivsky Sands, which is home to the national park of the same name, which is $116 \%$ more than last year and $922 \%$ more than in 2016 . One of the factors of positive dynamics of this indicator can be considered the presentation of the potential of the Park at exhibitions (UITT-2018, Opening of the tourist season in Kamyanska Sich) and productive cooperation of the park administration with tour operators and agents. This factor also influenced the increase in tourists at the Dzharilgatsky National Park. In 2018, it was visited by 45,000 tourists, which is $9.8 \%$ more than in 2017.

Also, an increase in the number of tourists is observed in National Park «Lower Dnieper» - in 2018 it was visited by 3720 tourists, which is $116 \%$ more than in 2017 . The main reason for the increase in tourist flows is the development of infrastructure and recreational activities in the park. One example of this is the launch in 2018 of a new water-marked excursion route in kayaks and boats «Dnieper Gilea». 
In 2018 , Askania-Nova was visited by 72,536 tourists, which is $11 \%$ less than in 2017. According to the director of the Askania-Nova Biosphere Reserve, Viktor Gavrilenko, the negative condition of the roads leading to a decrease in excursion flows. In 2018, on the section of the road R-47 Kherson-Nova Kakhovka-Genichesk, the entrance to Askania-Nova, a partial repair was carried out to improve this situation.

Based on the presented data on the attendance of national parks and reserves, it can be stated that it has grown significantly in ten years, more than six times. Despite the fact that the presented information does not allow to make a final conclusion about a certain trend, nevertheless, it is possible to note sharp increase in visiting of reserves since 2008 and stable, though insignificant growth in the following years.

National parks are the main resources for the development of ecological tourism. And, based on the level of their equipment, infrastructure, as well as unique facilities and services provided, tourists prefer certain parks. Despite a significant increase in the number of tourists in biosphere reserves and national parks, Ukraine is still unable to compete with other countries and is inferior to them in the organization of ecological tourism in the nature protected areas [15].

The essence of the problem of such low tourist attendance of Ukrainian national parks is the poorly developed ecotourism infrastructure in these areas, low funding, weak marketing and image of the objects. Ukraine, having a huge reserve of natural resources, is able not only to increase its position among the visited countries of ecotourism, but also in the future to take a leading position in this field. At the moment, Ukraine occupies a very modest place in the world ecotourism market. In Fig. 1 we can see the ratio of the average annual income from ecotourism of the leading countries.

Fig. 1. shows that the United States is significantly superior to other countries in terms of income from ecotourism, with an annual income of 14,000 million dollars. In Ukraine, the annual income from ecotourism is 10 million dollars, which is 1166

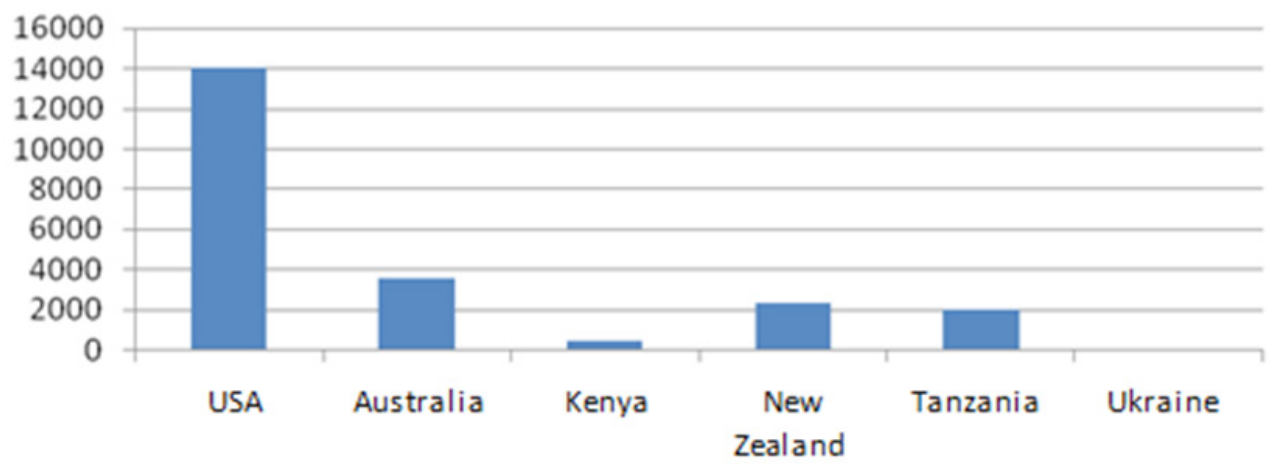

Fig. 1. The structure of income of different countries from ecotourism per year, in millions of dollars. Built on $[12,15]$ 
times less than in the United States. Even compared to other represented countries such annual income is only a drop in the ocean against their background. And this money should go to support nature conservation and local development.

Unfortunately, for a long time the development of ecological tourism in Ukraine was purely amateur. Only in recent years has there been a trend towards the formation of this type of tourism at the state level. In many areas, ecotourism can become a specialized industry that is a competitive alternative to economic activity.

Of great importance is the location of nature protected areas in our country, as the level of infrastructure and accessibility affect the choice of destination within Ukraine. Thus, in the western regions there are more natural areas, which allow to emphasize the development of ecotourism in these areas, so they have a much better developed tourist infrastructure, compared to the eastern regions [1]. In addition, they are closer to European countries, which can serve not only for the development of domestic tourism, but also inbound tourism.

\section{CONCLUSIONS}

Due to its natural potential, Ukraine is considered by the world community as the most promising country for the development of ecological tourism. In particular, the WTO named ecotourism among the three priority areas for the development of domestic and inbound tourism in Ukraine. In some regions of Ukraine, the process of ecological tourism development is already quite active, however, this direction should be combined into a single state strategic policy, which should aim at socio-economic development of regions and preserving their natural and ecological balance.

The priority tasks of ecological tourism development in the country are:

- training of qualified specialists for the industry;

- development of a wide range of new ecotourism products;

- use of flexible pricing policy;

- state assistance in promoting ecotourism products on the world market;

- joint work of regional authorities and local communities in the development of ecological tourism in regional protected areas;

- attracting domestic and foreign investments, motivating their participation, for example, by simplifying tax burdens or the desire of business people to participate in the development of the region.

Today, ecotourism is a complex interdisciplinary field that interconnects the interests of tourism, culture and ecology. Ecotourism is a phenomenon that characterizes the beginning of the 21 st century, which can have a powerful positive impact on the economy of individual regions and the whole country, as well as intensify the movement to protect and preserve the natural areas of our vast Ukraine. 


\section{REFERENCES}

1. Bilecz'ka, G. A. (2010), Rozvytok ekoturyzmu yak zasib ekonomichnoho zrostannya Khmel'nyts'koyi oblasti [Development of ecotourism as a means of economic growth of Khmelnytsky region], Herald of Khmelnytskyi national university, Vol. 2., №10, pp 245-247.

2. Blakbern, A. A. (2005), Regionalnye landshaftnye parki kak turistsko-rekreatsionnye predpriyatiya $\mathrm{v}$ kontekste ustoychivogo razvitiya turizma $\mathrm{v}$ Ukraine [Regional landscape parks as tourist and recreational enterprises in the context of sustainable tourism development in Ukraine], Herald of DITB. Series "Economics, organization and management of enterprises in the tourism sector", №9 pp., 190-196.

3. Bohush, L. H. (2008), Ekoturyzm yak vektor intehratsiyi sotsial'no-ekonomichnoyi ta ekolohichnoyi skladovykh staloho rozvytku [Ecotourism as a vector of integration of socio-economic and environmental components of sustainable development]. Avalable at: http://economics-of-nature. net/uploads/arhiv/2008/Bogush.pdf [Accessed 02 July 2020].

4. Derzhavna sluzhba statystyky v Ukrayini, (2020), [State Statistics Service of Ukraine] Avalable at: http://www.ukrstat.gov.ua [Accessed 22 September 2020].

5. Kozlovs'kyy, Ye.V. (2015), Pravove rehulyuvannya turystychnoyi diyal'nosti. [Legal regulation of tourist activity], Kyiv: Center for Educational Literature, 272 pp.

6. Lutska, N. I., Krykhovskyi I. Z. (2009), Marketynhova innovatsiina stratehiia rozvytku turystychnoho biznesu [Marketing innovation strategy of tourism business development], Investments: practice and experience, №6, pp.. 27-30.

7. Runtsiv, O. I. (2006), Problemy rozvytku ekolohichnoho turyzmu v Ukraini [Problems of development of ecological tourism in Ukraine] Bulletin of Scientific Research. Tourism series, №1, pp. 180-183.

8. Stupen, N. M. (2016) Svitovyi dosvid rozvytku ekolohichnoho turyzmu na rekreatsiinykh terytoriiakh [World experience in the development of ecological tourism in recreational areas] Balanced nature management, № 3, pp. 94-99, Avalable at: http://nbuv.gov.ua/UJRN/Zp_2016_3_17 [Accessed 24 September 2020].

9. Terytorii ta ob'iekty PZF Ukrainy, (2020) [Territories and objects of the nature reserve fund of Ukraine] Avalable at: http://nbuv.gov.ua/UJRN/Zp_2016_3_17 [Accessed 04 September 2020].

10. Shumlianska, N. V. (2014), Ekoturyzm yak forma doluchennia do pryrodnoi ta kulturnoi spadshchyny [Ecotourism as a form of joining the natural and cultural heritage], Culture of Ukraine, Vol. 47, pp. 107-115, Avalable at: http://nbuv.gov.ua/UJRN/Ku_2014_47_15 [Accessed 04 August 2020].

11. Fennell, D.A. (2008), Ecotourism: an Introduction, London: Routledge, 282 p.

12. Honey, M. (2008) Ecotourism and Sustainable Development: Who Owns Paradise? Washington DC: Island Press, $568 \mathrm{p}$.

13. International Union for Conservation of Nature. Avalable at: http://www.iucn.org [Accessed 25 August 2020].

14. The Travel \& Tourism Competitiveness Report. World Economic Forum, 2017, 519 p.

15. UNWTO Tourism Highlights, 2017 Edition. Avalable at: https://www.e-unwto.org/doi/ pdf/10.18111/9789284419029 [Accessed 25 June 2020].

\section{СПИСОК ВИКОРИСТАНОЇ ЛІТЕРАТУРИ}

1. Білецька Г. А. Розвиток екотуризму як засіб економічного зростання Хмельницької області [Текст] / Г. А. Білецька // Вісник Хмельницького національного університету. - 2010. - №10. - T. 2. - C. $245-247$.

2. Блакберн А. А. Региональные ландшафтные парки как туристско-рекреационные предприятия в контексте устойчивого развития туризма в Украине [Текст]/ А. А. Блакберн // Вісник ДІТБ. Серія «Економіка, організація і управління підприємствами в туристичній сфері» - 2005. - №9. - С. 190-196.

3. Богуш Л. Г. Екотуризм як вектор інтеграції соціально-економічної та екологічної складових 
сталого розвитку [Текст] / Л. Г. Богуш. - Режим доступу : http://economics-of-nature.net/ uploads/arhiv/2008/Bogush.pdf

4. Державна служба статистики в Україні [Дані, текст]. - Режим доступу: http://www.ukrstat. gov.ua

5. Козловський С.В. Правове регулювання туристичної діяльності. [Текст] Навч. посіб. - К. : Центр учбової літератури, 2015. -272 с.

6. Луцька Н. І. Маркетингова інноваційна стратегія розвитку туристичного бізнесу. [Текст] / Н. І. Луцька, І. 3. Криховський // Інвестиції: практика та досвід. - 2009. - №6. - С. 27-30.

7. Рунців О. I. Проблеми розвитку екологічного туризму в Україні [Текст] / О.I. Рунців // Вісник наукових досліджень. Серія «Туризм» - 2006. - Вип. 1. - С. 180-183.

8. Ступень Н. М. Світовий досвід розвитку екологічного туризму на рекреаційних територіях [Текст] / Н. М. Ступень // Збалансоване природокористування. - 2016. - № 3. - С. 94-99. Режим доступу: http://nbuv.gov.ua/UJRN/Zp_2016_3_17.

9. Території та об'єкти ПЗФ України [Дані, текст]. - Режим доступу: http://www.pzf.menr.gov. ua

10. Шумлянська Н. В. Екотуризм як форма долучення до природної та культурної спадщини [Текст] / Н. В. Шумлянська // Культура України. - 2014. - Вип. 47. - С. 108-115. - Режим доступу: http://nbuv.gov.ua/UJRN/Ku_2014_47_15

11. Fennell D.A. Ecotourism: an Introduction. [Текст] - 2008, London: Routledge, 282 p.

12. Honey M. Ecotourism and Sustainable Development: Who Owns Paradise? [Текст] - Washington DC: Island Press, 2008. - 568 p.

13. International Union for Conservation of Nature. [Data, text]. - Режим доступу: http://www.iucn. org

14. The Travel \& Tourism Competitiveness Report. World Economic Forum, 2017. [Data, text] - 519 p.

15. UNWTO Tourism Highlights, 2017 Edition. [Data, text] - Режим доступу: https://www.e-unwto. org/doi/pdf/10.18111/9789284419029.

Надійшла 25.10.2020 p.

Л. В. Транченко ${ }^{1}$, доктор економ. наук, професор

В. В. Яворська ${ }^{2}$, доктор геогр. наук, професор

К. В. Коломісць ${ }^{2}$, канд. геогр. наук, доцент

${ }^{1}$ Уманський національний університет садівництва,

кафедра туризму та готельно-ресторанної справи,

вул. Інститутська, 1, м. Умань, Черкаська обл., 20305, Україна

lydatranch@gmail.com

${ }^{2}$ Одеський національний університет імені I. I. Мечникова,

кафедра економічної та соціальної географії і туризму,

вул. Дворянська 2, м. Одеса, 65082, Україна

yavorskaya@onu.edu.ua

\section{НАПРЯМИ АКТИВІЗАЦЇ̈ РОЗВИТКУ ЕКОТУРИЗМУ В УКРАЇНІ}

\section{Резюме}

У даному досліджені піднімаються питання, пов'язані з сучасним станом екотуризму та перспектив його розвитку в нашій країні. Україна за оцінками Всесвітньої туристської організації має великий потенціал для розвитку екотуризму 
та можливість опинитися в списку лідируючих країн у цьому напряму. Однак існує ряд обмежень і проблем, які перешкоджають більш активному розвитку екотуризму в України. Метою статті є дослідити причини недостатнього розвитку екотуризму в Україні та обгрунтувати напрями його активізації в країні. Відмічено, що в Україні, на відміну від ряду зарубіжних країн, де існують більш точні методи підрахунку туристського потоку, дуже складно оцінити реальний потік відвідувачів національних парків, через відсутність однозначних методів обліку відвідувачів. Для популяризації екологічного туризму адміністрації національних природних парків рекомендовано презентувати парки на міжнародних туристичних виставках, активніше співрацювати з туроператорами та турагентами, розвивати інфраструктуру парку та рекреаційну діяльність в його межах, пропонуючи туристам нові маршрути.

Ключові слова: екологічний туризм, природоохоронні території, національні парки, заповідники, туристичні дестинації, туристичні потоки.

Л. В. Транченко ${ }^{1}$, доктор эконом. наук, профессор

В. В. Яворская ${ }^{2}$, доктор геогр. наук, профессор

Е. В. Коломиец ${ }^{2}$, канд. геогр. наук, доцент

${ }^{1}$ Уманьский национальный университет садоводства,

кафедра туризма и отельно-ресторанного дела,

ул. Институтская, 1, г. Умань, Черкасская обл., 20305, Украина

lydatranch@gmail.com

${ }^{2}$ Одесский национальный университет имени И. И. Мечникова, кафедра экономической и социальной географии и туризма, ул. Дворянская 2, г. Одесса, 65082, Украина

\section{НАПРАВЛЕНИЯ АКТИВИЗАЦИИ РАЗВИТИЯ ЭКОТУРИЗМА В УКРАИНЕ}

\section{Резюме}

Статья посвящена вопросам, связанным с современным состоянием экотуризма и перспектив его развития в нашей стране. Украина по оценкам Всемирной туристской организации имеет большой потенциал для развития экотуризма и возможность оказаться в списке лидирующих стран в этом направлении. Однако существует ряд ограничений и проблем, которые препятствуют более активному развитию экотуризма в Украине. Целью статьи является исследовать причины недостаточного развития экотуризма в Украине и обосновать направления его активизации в стране. Отмечено, что в Украине, в отличие от ряда зарубежных стран, где существуют более точные методы подсчета туристского потока, очень сложно оценить реальный поток посетителей национальных парков, из-за отсутствия однозначных методов учета посетителей. Для популяризации экологического туризма администрации национальных парков рекомендуется представить парки на международных туристических выставках, активно спиврацю- 
ваты с туроператорами и турагентами, развивать инфраструктуру парка и рекреационной деятельности в его пределах, предлагая туристам новые маршруты.

Ключевые слова: экологический туризм, природоохранные территории, национальные парки, заповедники, туристические дестинации, туристические потоки. 